\title{
Western Gas Sands Project Quarterly Basin Activities Report
}

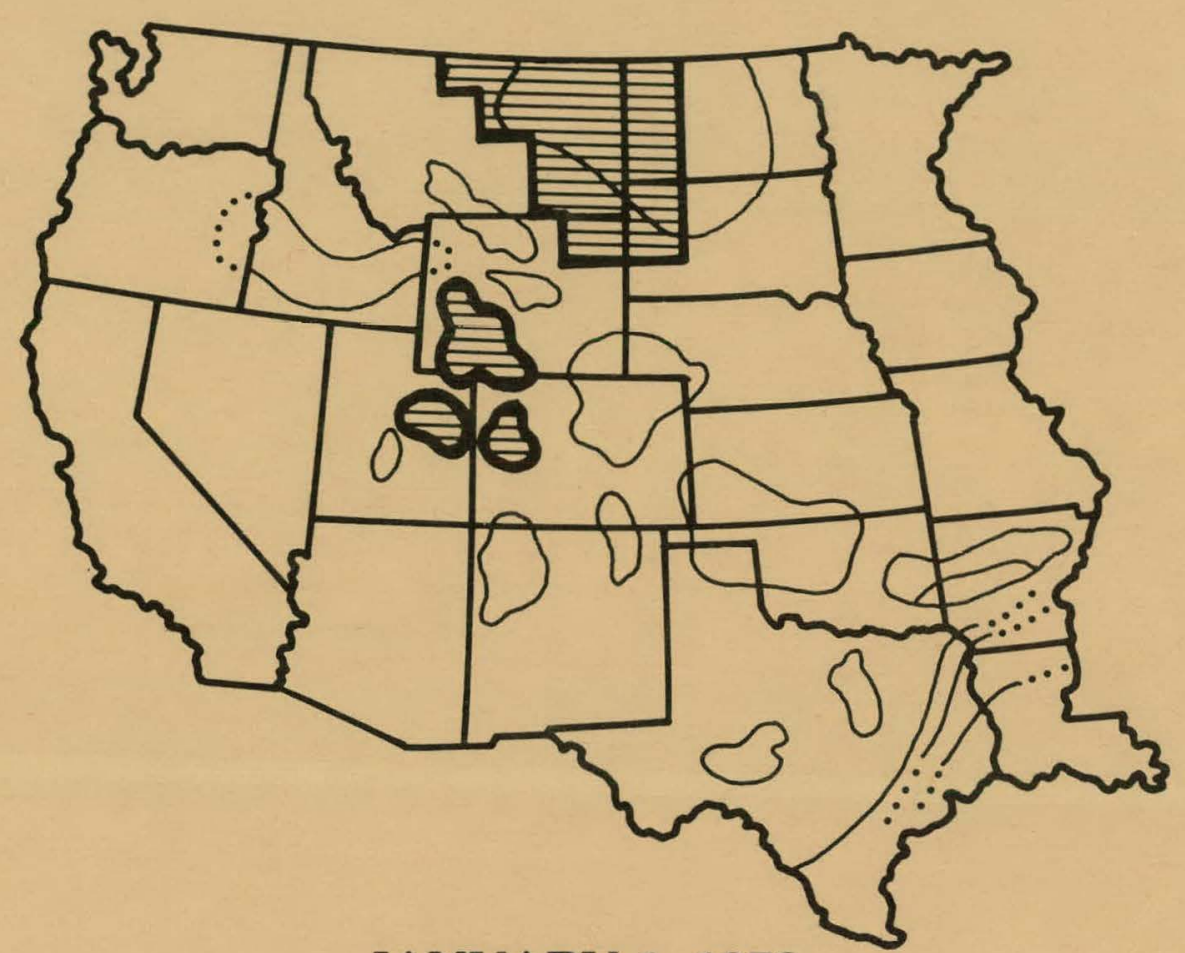

JANUARY 1, 1978

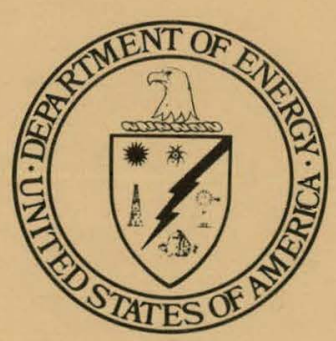

Prepared for

U.S. Department of Energy

Bartlesville Energy Research Center

Charles H. Atkinson

Project Manager

Compiled by CER Corporation

Las Vegas, Nevada

Contract EY-76-C-08-0655 


\section{DISCLAIMER}

This report was prepared as an account of work sponsored by an agency of the United States Government. Neither the United States Government nor any agency Thereof, nor any of their employees, makes any warranty, express or implied, or assumes any legal liability or responsibility for the accuracy, completeness, or usefulness of any information, apparatus, product, or process disclosed, or represents that its use would not infringe privately owned rights. Reference herein to any specific commercial product, process, or service by trade name, trademark, manufacturer, or otherwise does not necessarily constitute or imply its endorsement, recommendation, or favoring by the United States Government or any agency thereof. The views and opinions of authors expressed herein do not necessarily state or reflect those of the United States Government or any agency thereof. 


\section{DISCLAIMER}

Portions of this document may be illegible in electronic image products. Images are produced from the best available original document. 
THIS PAGE

\section{WAS INTENTIONALLY LEFT BLANK}


This report was prepared as an account of work sponsored by the United States Government. Neither the United States nor the United States DOE, nor any of their employees, nor any of their contractors, subcontractors, or their employees, makes any warranty, express or implied, or assumes any legal liability or responsibility for the accuracy, completeness, or usefulness of any information, apparatus, product or process disclosed, or represents that its use would not infringe privately owned rights.

Available from the National Technical Information Service, U.S. Department of Commerce, Springfield; Virginia 22161.

\begin{tabular}{|c|c|c|c|c|c|c|c|c|c|c|c|}
\hline \multirow[b]{2}{*}{$\begin{array}{l}\text { Page } \\
\text { range }\end{array}$} & \multicolumn{11}{|c|}{$\begin{array}{l}\text { NATIONAL TECHNICAL INFORMATION SERVICE PAPER COPY PRICES } \\
\text { EFFECTIVE JAN. } 1,1976\end{array}$} \\
\hline & $\begin{array}{l}\text { Domestic } \\
\text { price }\end{array}$ & $\begin{array}{l}\text { Page } \\
\text { range }\end{array}$ & $\begin{array}{c}\text { Domestic } \\
\text { price }\end{array}$ & $\begin{array}{l}\text { Page } \\
\text { range }\end{array}$ & $\begin{array}{c}\text { Domestic } \\
\text { price }\end{array}$ & $\begin{array}{l}\text { Page } \\
\text { range }\end{array}$ & $\begin{array}{c}\text { Domestic } \\
\text { price }\end{array}$ & $\begin{array}{l}\text { Page } \\
\text { range }\end{array}$ & $\begin{array}{c}\text { Domestic } \\
\text { price }\end{array}$ & $\begin{array}{l}\text { Page } \\
\text { range }\end{array}$ & $\begin{array}{c}\text { Domestic } \\
\text { price }\end{array}$ \\
\hline 001.025 & $\$ 3.50$ & $126 \cdot 150$ & $\$ 6.00$ & $251 \cdot 275$ & $\$ 9.00$ & 376.400 & $\$ 10.75$ & $501-525$ & $\$ 12.75$ & $701 \cdot 800$ & $\$ 18.75$ \\
\hline 026.050 & $\$ 4.00$ & 151.175 & $\$ 6.75$ & $276-300$ & $\$ 9.25$ & 401.425 & $\$ 11.00$ & $526-550$ & $\$ 13.00$ & $801-900$ & $\$ 21.25$ \\
\hline $05 i 075$ & $\$ 4.50$ & 176.200 & $\$ 7.50$ & 301325 & $\$ 9.75$ & 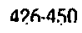 & $\$ 11.75$ & 551.575 & $\$ 13.50$ & $901 \cdot 1000$ & $\$ 23.75$ \\
\hline $076 \cdot 100$ & $\$ 5.00$ & 201.225 & $\$ 7.75$ & $326 \cdot 350$ & $\$ 10.00$ & 451.475 & $\$ 12.00$ & $576-600$ & $\$ 13.75$ & $1001 \cdot 1100$ & $\$ 282.5$ \\
\hline $101 \cdot 125$ & $\$ 5.50$ & $226-250$ & $\$ 8.00$ & 351.375 & $\$ 10.50$ & 476.500 & $\$ 12.50$ & 601.700 & $\$ 16.25$ & $1101 \cdot 1200$ & $\$ 32.75$ \\
\hline
\end{tabular}

For additional pages, add $\$ 4.50$ for each beginning 100 pages. Add $\$ 2.50$ per copy for foreign price.

Microfiche $\$ 3.00$ (domestic) $\$ 4.50$ (foreign).

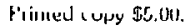




\section{CONTENTS}

Page

1. INTRODUCTION ..................... 1

2. NORTHERN GREAT PLAINS PROVINCE . . . . . . . . . . . 4

2.1 General Geologic Description ............. 4

2.2 Basin Activity ................ 4

3. GREATER .GREEN RIVER BASIN . . . . . . . . . . . . . 12

3.1 General Geologic Description ........... . 12

3.2 Basin Activity .. . . . . . . . . . . 13

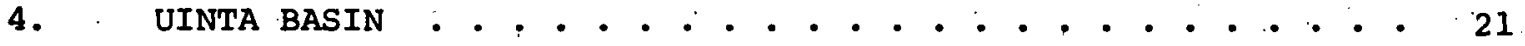

4.1 General Geologic Description ............. 21

4.2 Basin Activity ................ 21

5. PICEANCE BASIN . . . . . . . . . . . . . . 26

5.1 General Geologic Description . .................. 26

5.2 Basin Activity . . . . . . . . . . 27 


\section{FIGURES}

$\underline{\text { Page }}$

FIGURE 1-1 MAP OF WESTERN UNITED STATES SHOWING

AREAS OF INTEREST . . . . . . . . . . . . . . 2

FIGURE 2-1 MAP OF NORTHERN GREAT PLAINS PROVINCE . • • • . . 6

FIGURE 2-2 WEST-EAST DIAGRAMMATIC CROSS SECTION OF EASTERN MONTANA (NORTHERN GREAT PLAINS

PROVINCE) . . . . . . . . . . . . . 8

FIGURE 2-3 CORRELATION CHART OF CRETACEOUS ROCKS OF THE NORTHERN GREAT PLAINS PROVINCE . . . . . . . . . 9

FIGURE 3-1 MAP OF GREATER GREEN RIVER BASIN . . . . . . . . . . 14

FIGURE 3-2 SCHEMATIC NORTHEAST-SOUTHWEST CROSS SECTION

FIGURE 3-3 STRATIGRAPHIC CORRELATION CHART OF THE GREATER GREEN RIVER, PICEANCE AND UINTA BASINS • • • . . i i

FIGURE 4-1 MAP OF UINTA BASIN . . . . . . . . . . . 22

FIGURE 4-2. EAST-WEST DIAGRAMMATIC CROSS SECTION OF THE UINTA BASIN . . . . . . . . . . . . . . 23

FIGURE 5-1 MAP OF PICEANCE BASIN . . . . . . . . . . . . 28

FIGURE 5-2 SCHEMATIC EAST-WEST CROSS SECTION OF THE PICEANCE BASIN . . . . . . . . . . . . . 30

FIGURE 5-3 TYPICAL STRATIGRAPHIC RELATIONSHIPS OF LENTICULAR SANDS IN THE UPPER CRETACEOUS AND LOWER TERTIARY OF THE PICEANCE BASIN . . . . . . . . 31 


\section{TABLES}

Page

TAELE $1-1$

TABLE 2-1

TABLE 3-1.

TABLE $4-1$

TABLE 5-1
MAJOR STRATIGRAPHIC AND TIME DIVISIONS . . . . . . 3

INFORMATION ON CALLED OUT WELLS - NORTHERN

GREAT PLAINS PROVINCE .............. . 7

INFORMATION ON CALLED OUT WELLS - GREATER

GREEN RIVER BASIN . . . . . . . . . . . . 15

INFORMATION ON CALLED OUT WELLS - UINTA BASIN . . . . 24

INFORMATION ON CALLED OUT WELLS - PICEANCE BASIN . . 29 


\section{INTRODUCTION}

The quarterly basin activity report is a summation of information on geology and drilling activity in the four primary study areas of the Western Gas Sands Project. The areas of interest, shown on Figure 1-1, are the Greater Green River Basin, the Piceance Basin, the Uinta Basin and the Northern Great Plains Province. Additional marginally productive areas indicated on the map are not currently being discussed in this report. A short description of these areas can be found in the "Western Gas Sands Project Plan, August 1, 1977."

Table 1-1 shows the relationship between the major stratagraphic divisions and time referred to in this report. In addition, the geology of each study area is briefly outlined using maps, correlation charts and cross sections.

Drilling activity is discussed for the months of October, November, and December, 1977, with the major emphasis on wells located in low permeability sandstone areas, having significant gas production and utilizing hydraulic fracturing treatments.

The drilling information was obtained primarily from "The Rocky Mountain Region Report" published by Petroleum Information Corporation on a daily basis. Another source of information was the "Montana Oil and Gas sournal" which is released weekly. 


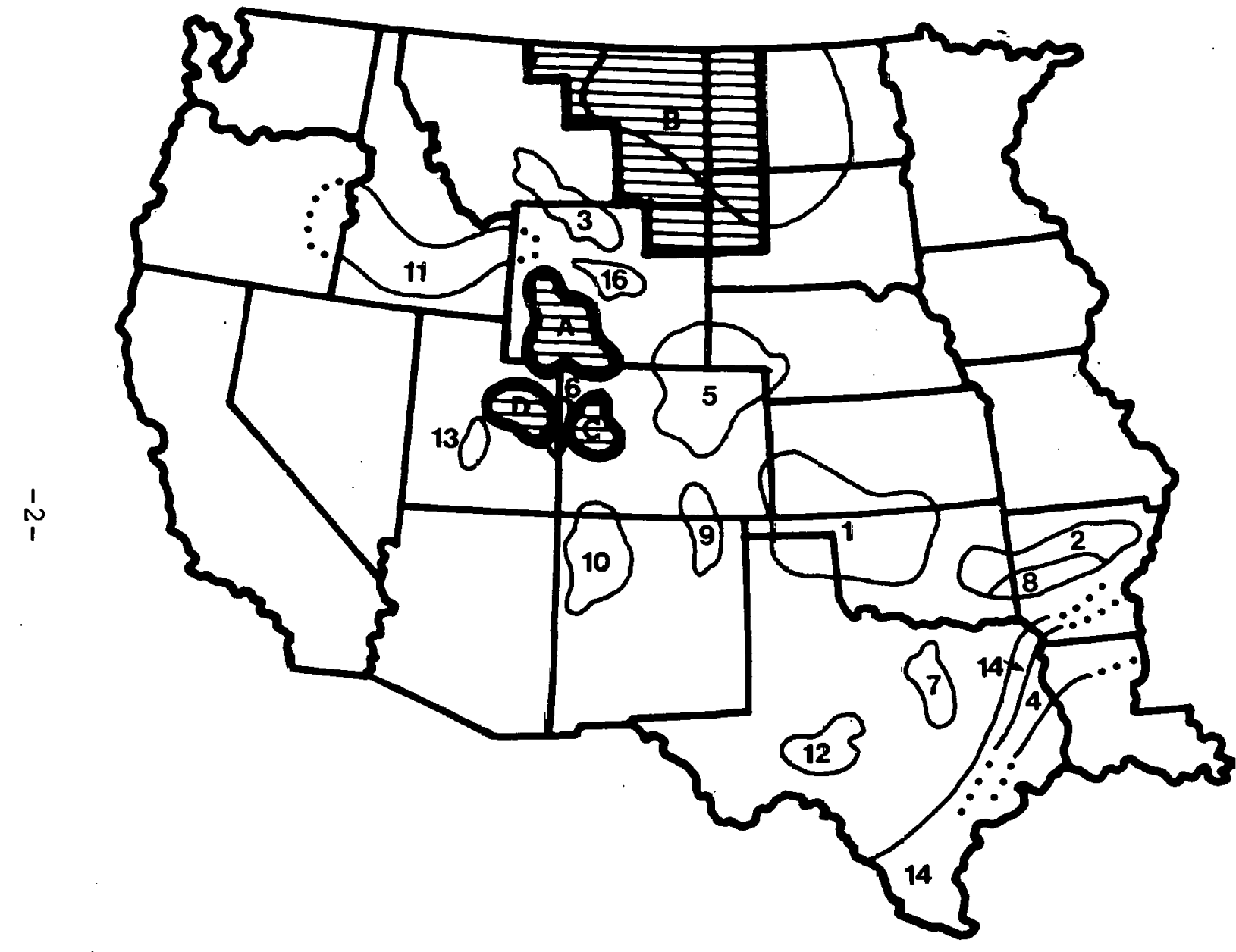

PRIMARY STUDY AREAS

A. GREATER GREEN RIVER BASIN

B. NORTHERN GREAT PLAINS PROVINCE

C. PICEANCE BASIN

D. UINTA BASIN

ADDITIONAL LOW PERMEABILITY SANDSTONE AREAS

1. ANADARKO BASIN

2. ARKOMA BASIN

3. BIG HORN BASIN

4. COTTON VALLEY TREND

5. DENVER BASIN

6. DOUGLAS CREEK ARCH

7. FORT WORTH BASIN

8. OUACHITA MOUNTAINS PROVINCE

9. RATON BASIN

10. SAN JUAN BASIN

11. SNAKE RIVER DOWNWARP

12. SONORA BASIN

13. WASATCH PLATEAU

14. WESTERN GULF BASIN

15. WILLISTON BASIN

16. WIND RIVER BASIN

FIGURE 1-1 MAP OF WESTERN UNITED STATES, SHOWING AREAS OF INTEREST 
TABLE 1-1 MAJOR STRATIGRAPHIC AND TIME DIVISIONS

\begin{tabular}{|c|c|c|c|c|}
\hline \multirow{6}{*}{$w_{1}^{1}$} & ERA & SYSTEM OR PERIOD & SERIES OR EPOCH & $\begin{array}{c}\text { APPROXIMATE AGE } \\
\text { (IN MILLIONS OF } \\
\text { YEARS BEFORE } \\
\text { PRESENT) }\end{array}$ \\
\hline & & QUATERNARY & $\begin{array}{l}\text { RECENT } \\
\text { PLEISTOCENE }\end{array}$ & \\
\hline & 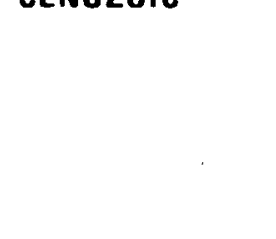 & TERTIARY & $\begin{array}{l}\text { PLIOCENE } \\
\text { MIOCENE } \\
\text { OLIGOCENE } \\
\text { EOCENE } \\
\text { PALEOCENE }\end{array}$ & $.5-8$ - \\
\hline & MESOZOIC & $\begin{array}{l}\text { CRETACEOUS } \\
\text { JURASSIC } \\
\text { TRIASSIC }\end{array}$ & & \\
\hline & PALEOZOIC & $\begin{array}{l}\text { PERMIAN } \\
\text { PENNSYLVANIAN } \\
\text { MISSISSIPPIAN } \\
\text { DEVONIAN } \\
\text { SILURIAN } \\
\text { ORDOVICIAN } \\
\text { CAMBRIAN }\end{array}$ & v & -1 \\
\hline & PRE-CAMBRIAN & & & $4,500 \pm$ \\
\hline
\end{tabular}




\section{NORTHERN GREAT PLAINS PROVINCE}

\subsection{General Geologic Description}

This province comprises an area of about 125,000 square miles. It includes the western part of the Willistnn Basin, the northorn part of the Powder River Basin and the southeastern part of the Western Canada Basin. The region covers two-thirds of Montana, western North Dakota, northeastern Wyoming and northwestern South Dakota and is much larger than the Piceance, Uinta and Green River Basins combined (Figure 2-1).

The sedimentary section is about 10,000 ft thick on the eastern side of tho Northern Great Flains Psuvinle. Eretaceous rocks crop out over most of the province except in the central part of the williston Basin where Tertiary rocks are preserved. Paleozoic rocks primarily produce oil, while Mesozoic rocks produce both oil and gas. The Tertiary system, representative of similar depositional environments in the basins to the south, has not been productive but could be in the central part of the Williston Basin.

Upper Cretaceous depositional environments include transgressive and regressive sandstones and siltstones enclosed in thick sequences of marine shale and are thin and discontinuous with low permeabilities.

The Upper Cretaceous maxine tight sands have produced gas from the Bowdoin and Cedar Creek Fields: The Bowdoin Field produces from the Carlile and Greenhorn Formations while the Cedar Creek Field produces from the Judith River and Eagle Formations (Figure 2-2). The gas is stratigraphically entrapped although the fields are located on structural highs. Drilling depths to objective reservoirs are quite shallow, averaging less than 4,000 ft. The thickness of the total Upper Cretaceous section in this province is about 4,000 ft.

The producing trend has been extensively developed in Alberta and Saskatchewan where the geologic characteristics are similar.

\subsection{Basin Activity}

This basin review covers primarily the activity in the significant upper Cretaceous sands of Montana. The Judith River and Eagle Formations represent the youngest production, followed by the Carlile (Bowdoin Sands) and Greenhorn (Phillips Sands), (Figure 2-3).

The Montana Annual Review for 1976 lists production of natural gas in Montana at nearly 41 billion cubic feet(BCF), up slightly from 1975 . 
To better present the production data, Montana will be divided into northern and southern areas separated by the $47^{\circ}$ latitude line which is near the northern part of the Cedar Creek Anticline.

\subsubsection{Northern Area}

In 1976, added interest was generated in the shallow (less than 2,000 ft) Judith River, Eagle, Bowdoin, and Phillips Sands. Most activity was concentrated in the Bowdoin Dome of Phillips and Valley Counties and the Bearpaw Arch of Blaine, Chouteau and Hill Counties.

Of the 80 wells in Phillips County, 63 were completed as Bowdoin Sand gas wells. Bowdoin Sands primarily produce from the Bowdoin Dome with some production just west and southwest of the Dome. The exception is Bowdoin equivalent production in the Ferdig Member of the Mancos River Formation southeast of the Bearpaw Uplift. The deeper Phillips Sands are more widespread and produce over a greater area than the Bowdoin Sands. For example, Phillips Sands are productive around the Bowdoin Dome in northern Blaine County and in the northeast corner of Liberty County. As of April 1977, the Western Oil Reporter indlcated that more than 150 gas wells were shut in on the northern extension of the Bowdoin Dome waiting for the completion of a pipeline. The original field to the south is presently on stream with several hundred producing wells. Recent Eagle wells are also producing or capable of producing on the southeast side of the Bowdoin Dome, Valley County. Cumulative production through 1976 for the Bowdoin Dome amounts to over 140 BCF. Major operators on the Dome are Kansas-Nebraska Natural Gas Co. (Midlands Gas Corp.), Joseph Paine and Associates, Miami Oil Producers, and Odessa Natural Corp.

Joseph Paine and Associates recently completed 14 producing wells from the Bowdoin and Phillip Sands north of the Bowdoin Field at about 1,300 to $1,800 \mathrm{ft}$. The average initial production flow was 633 thousand cubic feet per day (MCFD) with a frac size of about 35,000 lbs of sand plus acid. One of three wells by Paine and Associates received an initial production figure of 2,604 MCFD from Bowdoin and Phlllips Sands at 1,282 and $1,491 \mathrm{ft}$, respectively; the location is shown on Figure 2-1 by callout No. 1 with specific information given in Table 2-1. Just north of this area Paine recently completed another Bowdoin and Phillips test with similar statistics. Shenandoah Oil is also active in this area with seven Phillips and Bowdoin tests planned.

West of Bowdoin Field, in Hill, Blaine, and Chouteau Counties, production is from the Tiger Ridge and Bullwacker Units in the Bearpaw Arch area. Here production is from the Judith River and Eagle Sands. Total wells drilled in the Bearpaw area are estimated to number as high as 1,500. In 1975, the Montana Oil and Gas Commission listed over 200 wells drilled in this area, of which 159 were development and 50 were 


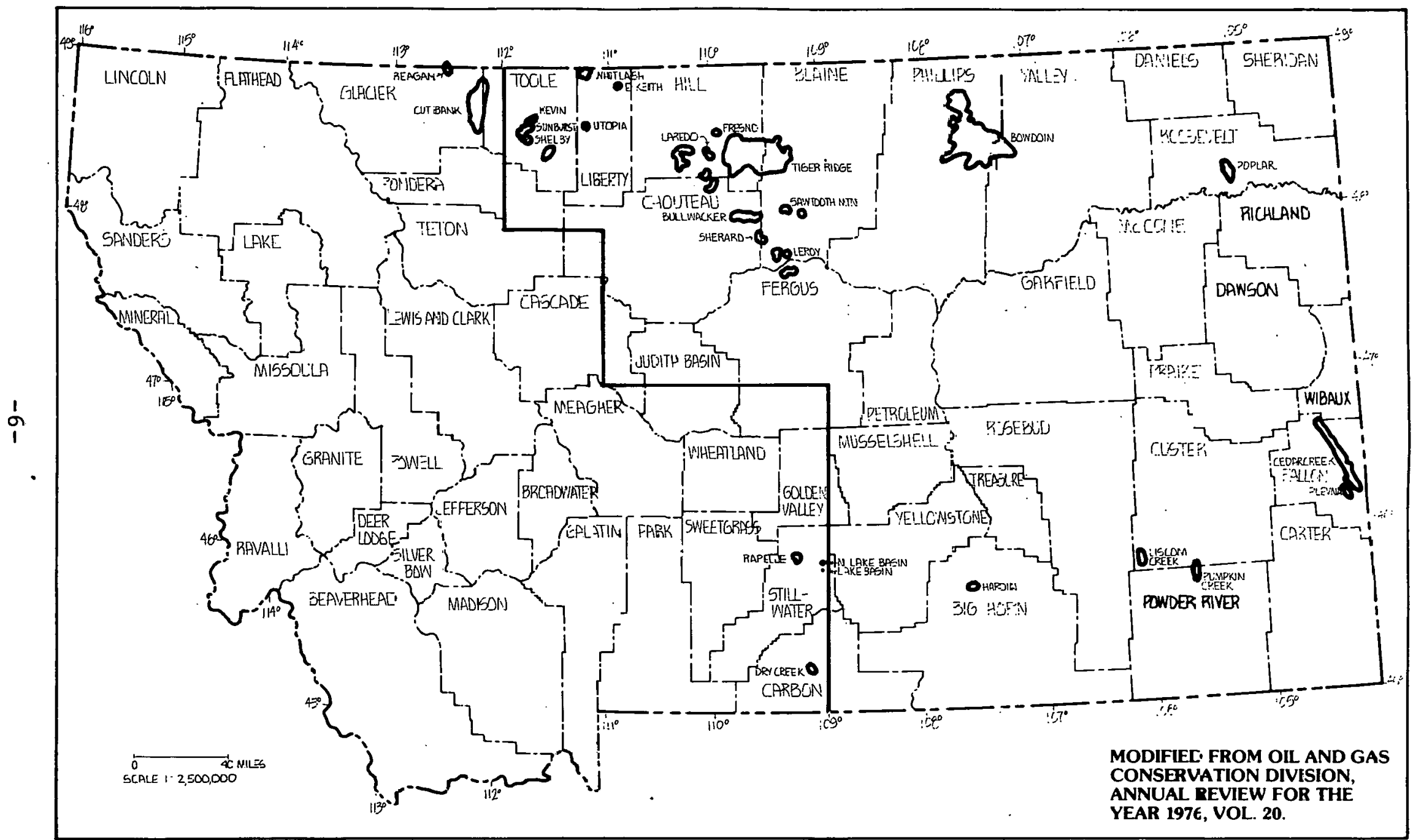

FIGURE 2-1 MAP OF NORTHERN GREAT PLAINS PROVINCE IN MONTANA 
TABLE 2-1

INFORMATION ON CALLED OUT WELLS NORTHERN GREAT PLAINS PROVINCE

\author{
1. Joseph J.C. Paine \& Assoc. \\ $\# 1$ - 1262 Scott \\ 12-T36N-R31E \\ Phillips County, Montana \\ Bowdoin Prod. $(1,282-1,341)$ ft gross \\ Phillips Prod. $(1,491-1,543)$ ft gross \\ Development Gas Well \\ Frac - 70,000 lbs of sd \\ $660 \mathrm{BW}$ \\ IPF- 2,604 MCFD (commingled) \\ 2. Montana Power \\ 1-10 Montana Industrial \\ 10-T7S-R21E \\ Carbon County, Montana \\ 1st Frontier Prod. $(4,209-4,221) \mathrm{ft}$ \\ Development Gas Well \\ Frac - 10,000 1bs of sd \\ IPF - 227 MCFD
}




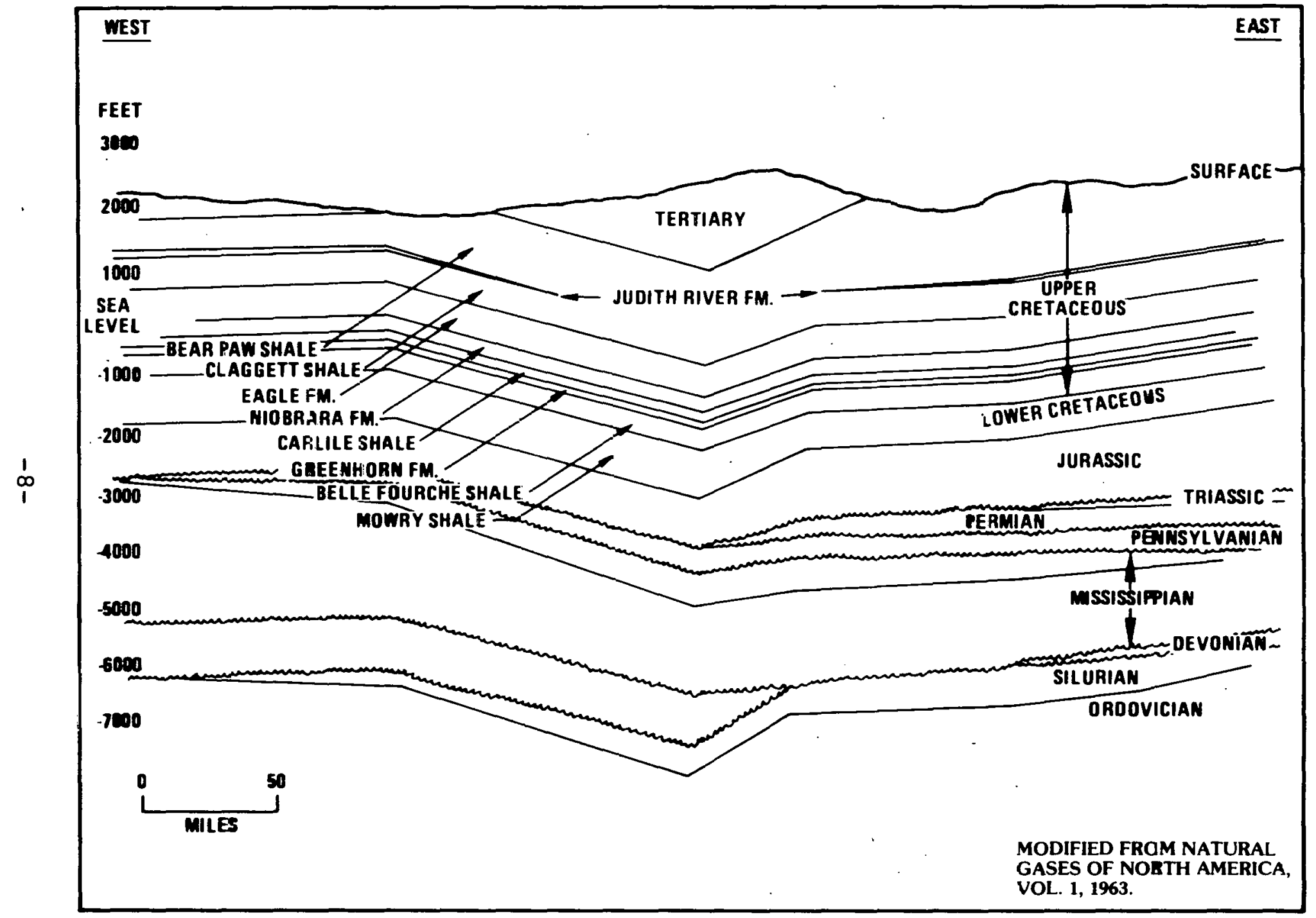

FIGURE 2-2 WEST-EAST DIAGRAMMATIC CROSS SECTION OF EASTERN MONTANA (NORTHERN GREAT PLAINS PROVINCE) 


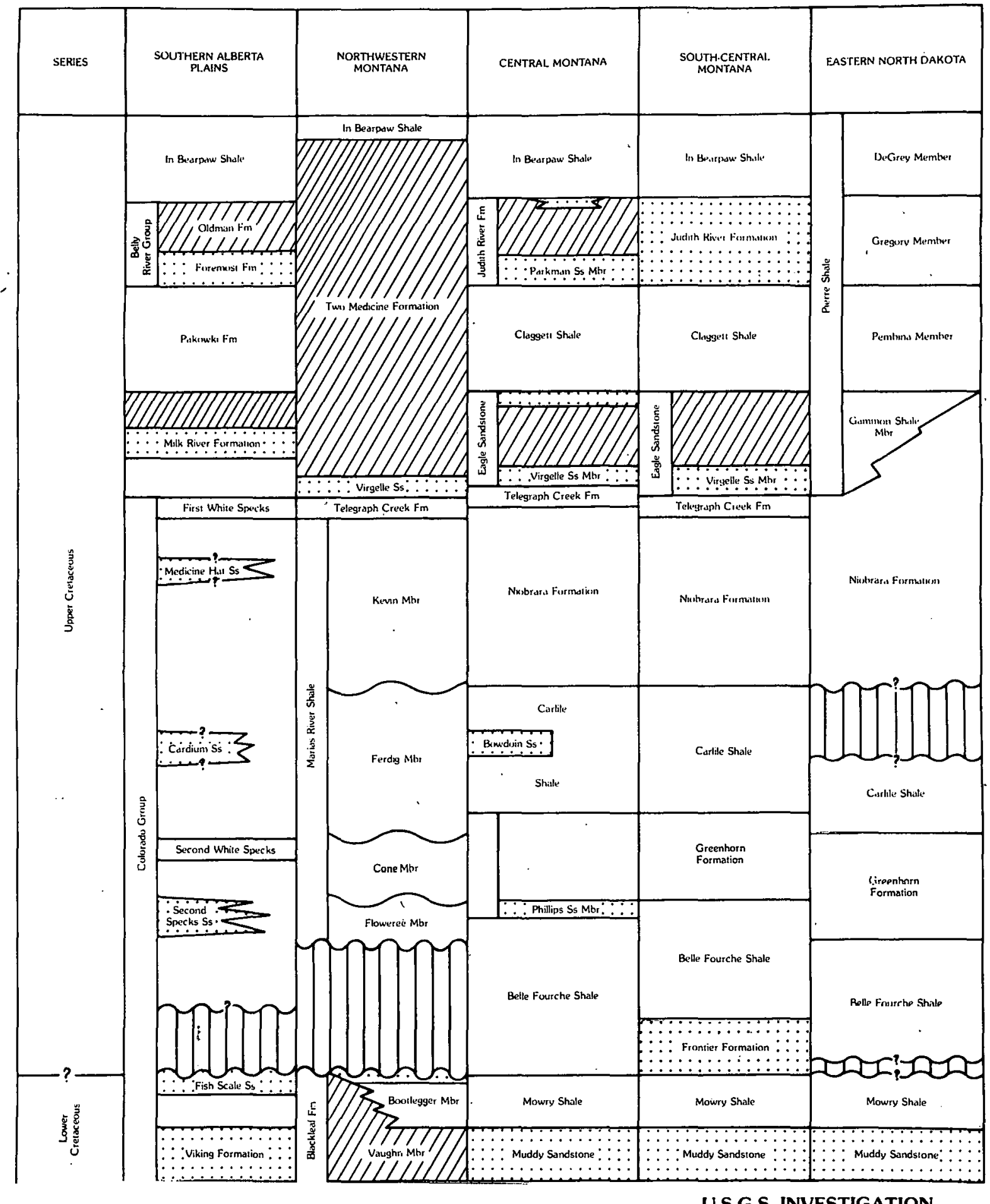

U.S.G.S. INVESTIGATION Marme Siltstime and Shale CHART OC-70, PUBLISHED BY THE U.S. GEOLOGIC

SURVEY, 1976.

777 Nonmarine Rocks

2. Sandstone-Nearshore, Shoreline and Aluvial

$\star \quad$ Upper Creaceecus Priducing 2 mities

\section{FIGURE 2-3 CORRELATION CHART OF CRETACEOUS ROCKS OF THE NORTHERN GREAT PLAINS PR̄OVINCE}


exploratory. In 1976, production from Tiger Ridge was over $14.7 \mathrm{BCF}$; the Bullwacker, Sherard, Fresno, and Sawtooth Mountain Fields accounted for another $2.5 \mathrm{BCF}$. Major operators in this area are Fuelco, Lyon Oil, Wise Oil, Montana Power Co., J. Burns Brown, and Tricentrol U.S., Inc.

Northeast of Tiger Ridge in Blaine County, Lyon Oil has about ten wells with several more wells in the planning stage. Information on these wells is very restricted, although at least one well is believed to be capable of producing 2,000 MCFD. Phillips potential is possible in some of these wells.

Northwest of Tiger Ridge in the East Keith Field, Liberty County, several wells are producing from often fraced Phillips (Sernnd white snecks) Sanda. The cumulative production in the East Keith Field to 1974 including some Lower cretaceous production, amounted to 26 million cubic feet (MMCF).

Poplar Field, Roosevelt County, has some Judith River production but these wells are quite old and very little data is available.

Fracture treatments are not normally necessary in the Bearpaw Arch area. However, in the northern part of the Bowdoin Dome structure, treatments of 30,000 to $50,000 \mathrm{lbs}$ of sand are bejng used as noted from the Paine wells.

\subsubsection{Southern Area}

South of the $47^{\circ}$ latitude line, the fields are generally smaller, except tor those in the Cedar Creek Anticline area of Fallon County. Cedar Creek and Plevna Fields produce from the Judith River and Eagle Formations. Over 200 wells have been drilled on this structure with cumulative production to 1977 being over 135 BCF of gas. Although most of these wells are quite old, Pacer Resources, Inc. drilled and fractured an Eagle test in 1976. Pacer later drilled five more Eagle tests in this area; information about the wells was not released.

West of Cedar Creek, Custer and Powder River Counties have Eagle (Shannon) production at Liscom Creek and Pumpkin Creek Fields. At Liscom Creek there are about 12 wells producing from the Shannon. Cumulative production is over one BCF of gas, with initial field production that began in late 1972. In Pumpkin Creek there are about nine producing Shannon wells. Production figures for 1976 (731 MMCF) indicate that Pumpkin Creek will probably be a better producing field than Liscom Creek ( 317 MMCF).

West of Liscom Creek, there are several small fields producing from Upper Cretaceous Sands. Rapelje Field (Stillwater County) produces from the Judith River, Claggett, and Eagle (Virgille) Formations. The claggett production in this field is significant and may have potential 
in other areas of the state and should be evaluated accordingly. The last two years' production figures give a total of over a billion cubic feet of gas for this field.

South of Rapelje, there is Eagle (Virgille), Telegraph Creek and Frontier production in North Lake Basin and Lake Basin Fields. The Telegraph Creek Formation lies just below the Eagle and the Frontier is just above the top of the Mowry (Lower Cretaceous) Formation. North Lake Basin cumulative production to 1975 is 8 BCF. Lake Basin cumulative production to 1975 is $500 \mathrm{MMCF}$ and has produced another 1.5 billion during the last two years.

The Dry Creek Field in Carbon County produces from the Eagle and Frontier Formations as well as the Lower Cretaceous Greybull Formation (callout 2). Cumulative production to 1974 is listed as 54 BCF of gas, with initial production beginning in 1931, and including some Greybull production.

East of Billings, Montana, in Big Horn County, is the Hardin Field with Frontier production. During the last two years, production totaled about $54 \mathrm{MMCF}$ of gas.

Fracturing in the southern area is done primarily in the area of Frontier production, evidenced in Hardin and Dry Creek Fields. There has been some fracturing of the Eagle and Telegraph Creek Sands in the Lake Basin Field, and of the Eagle in the Plevna Field near the Cedar Creek Anticline. A normal fracture treatment is between 30,000 and $40,000 \mathrm{lbs}$ of sand.

There are three major zones in southeastern Alberta, Canada, that produce gas from rocks equivalent in age to the Eagle, Niobrara, and Phillips Units of Montana. They are the Milk River (Eagle), Medicine Hat (Niobrara) and Second White Specks (Phillips) Units.

A large part of the Upper Cretaceous and Lower Cretaceous sections are made up of marine sands and shales which have significant potential for gas. A complete evaluation of presently non-producing zones as well as producing zones should be undertaken. This would involve coring, a complete suite of geophysical logs and production testing.

A most significant event in the southern area is the opening of the first gas field in South Dakota. The discovery was made by Jerry McCutchin, Jr. in Harding County, located in the northwest part of the state. The first well flowed 980 MCFD from the Shannon through perforations at 1405 to 1411 feet. This production is from natural flow. This is South Dakota's first gas well and its first production above Pennsylvanian. The nearest production from the Shannon is in the Pumpkin Creek Field of Montana, 90 miles to the west.

The second well was not productive and currently results from the third well are not available. 


\section{GREATER GREEN RIVER BASIN}

\subsection{General Geologic Description}

The Greater Green River Basin, shown by Figure 3-1, covers about 20,000 square miles of southwest Wyoming. It includes the Green River Basin proper; the eastern sub-basins of the Green River including the Red Desert, the Washakie, and Sand Wash Basins; and the Wamsutter Arch. The Vermilion Basin, a sub-basin of the Sand Wash south of the Rock Springs Uplift, and the Bridger Basin to the west, a sub-basin of the Green River, are sometimes referred to as separate basins.

The Greater Green River Basin is bounded hy the Wynming Thrust Belt on the west, the Wind River Mountains on the northeast, by the Sweetwater Arch, Rawlins Uplift, and Sierra Madre Mountains on the east, and on the south by the Uinta Mountains and the Axial. Basin Arch.

The Green River Basin west of the Rock Springs Uplift contains 30,000 feet of sedimentary rocks, while the basins to the east of the Uplift contain thicknesses exceeding 20,000 feet. The sediments range in age from Cambrian to Late Eocene. Gas and oil have been produced from rocks ranging in age from Mississippian to Eocene, while older production has been found along the northern end of the Rawlins Uplift east of the Red Desert. Figure 3-2 shows the cross-section of the basin.

The depositional environments of the Upper Cretaceous include transitional marine deposits above and below the Mesaverde. In contrast, in the Ficeance and Uinta Basins, the upper non-marine Mesaverde either conformably or unconformably grades into the overlying non-marine Tertiary. Here, the main part of the Mesaverde (Ericson Sandstone) is non-marine although the Almond Formation of the Mesaverde which lies above the Ericson is transitional non-marine to marine. The marine Lewis Shale, which lies above the Mesaverde in the eastern part of the area, is in turn overlain by the non-marine Lance Formation. The Lance is difficult to separate from the overlying Paleocene Fort Union Formation as both have low, swampy-type non-marine sediments. The younger Eocene Wasatch Formatinn gradually shows the gradation into the typical Tertiary non-marine, floodplain fluvial environment, typified in the Piceance and Uinta Basins: In the Piceance. and Uinta Basins, most hydrocarbon trapping possibilities are stratigraphic with some structural influence. Gas has been produced from the Mesaverde and from lenticular sandstones of early Tertiary age in the western part of the Green River Basin (west of the Rock Springs Uplift).

To the east of the Rock Springs Uplift, the Almond Formation (Mesaverde) accounts for most of the oil and gas production. In this area of the Red Desert, Washakie and Sand Wash Basins, a thickened Tertiary section requires excessive drilling depths to the Cretaceous. 
The Mesaverde is exposed at various locations around the basin, including the Rock Springs Uplift. Drilling depths to penetrate the entire Mesaverde section in deeper parts of the basin, as in the Pinedale Unit of the Green River Basin, can exceed 16,000 feet. The thickness of the Mesaverde here is in excess of 3,400 feet. The Lance-Lewis-Almond section is 2,500 feet thick, while the overlying Ft. Union Formation is over 3,000 feet thick; Eocene sediments, including the wasatch, extend to the surface, (Figure 3-3) .

\subsection{Basin Activity}

Most drilling activity in the Greater Green River Basin is in Sweetwater County and the western part of Carbon County. Carbon County activity is primarily directed toward the Mesaverde Group or specific formations of this group, such as the Almond or Ericson. Sun Oil is active in this county and has a well with 11,000 MCFD from the Mesaverde formation, utilizing a fracture treatment. This well location is shown on Figure 3-1 by callout No.1, with specific well information given in Table 3-1. Amoco Production, Rainbow Resources, Marathon Oil and Davis Oil are some of the major operators in this area. Depths to the Mesaverde objectives range from 8,000 to $12,000 \mathrm{ft}$ with frac treatments varying from 40,000 to over 200,000 lbs. Rainbow Resources, however, generated some Late Cretaceous Lance and Lewis production from the Smith Ranch Field with a net initial flow of 490 MCFD. Sweetwater County, the major supplier of gas for the Greater Green River Basin, has numerous wells in various stages of operation in this large and productive county (callout 2). Currently there are about 65 Mesaverde tests in progress in this area, and a significant increase in production from the Lewis Formation has been evidenced during the last two months. One of the major fields for tight gas sands activity and successful frac treatments is the Wamsutter Field in which Amoco Production, Marathon Oil and Champlin Petroleum are doing a significant amount of work. Activity is directed toward the Almond and Ericson Formations of the Mesaverde Group at depths averaging a little over 10,000 ft. Frac operations have varied from 50,000 to 1,000,000 lbs of sand. Even though the area has been sparsely drilled, some wells have produced more than 10 MMCFD. Amoco Production also has 20 wildcat wells either staked or being drilled north of the Wamsutter areas. Just.to the north of this play, and east and west of Sentinel Ridge, Amoco, Davis and Michigan-Wisconsin Pipeline have seven more Mesaverde tests with similar drilling depths of 10,000 to $15,000 \mathrm{ft}$.

In the Hay Reservoir Field, also north of Wamsutter Field, Davis Oil has several Mesaverde tests in operation. One well, which produced from the Lewis, generated an initial production of 4,740 MCFD from a depth of $10,000 \mathrm{ft}$ (callout 3). Apache Corporation and Texas Oil and Gas have three wildcat Rock Springs (Mesaverde) tests on location or drilling north of the Hay Reservoir Field. 


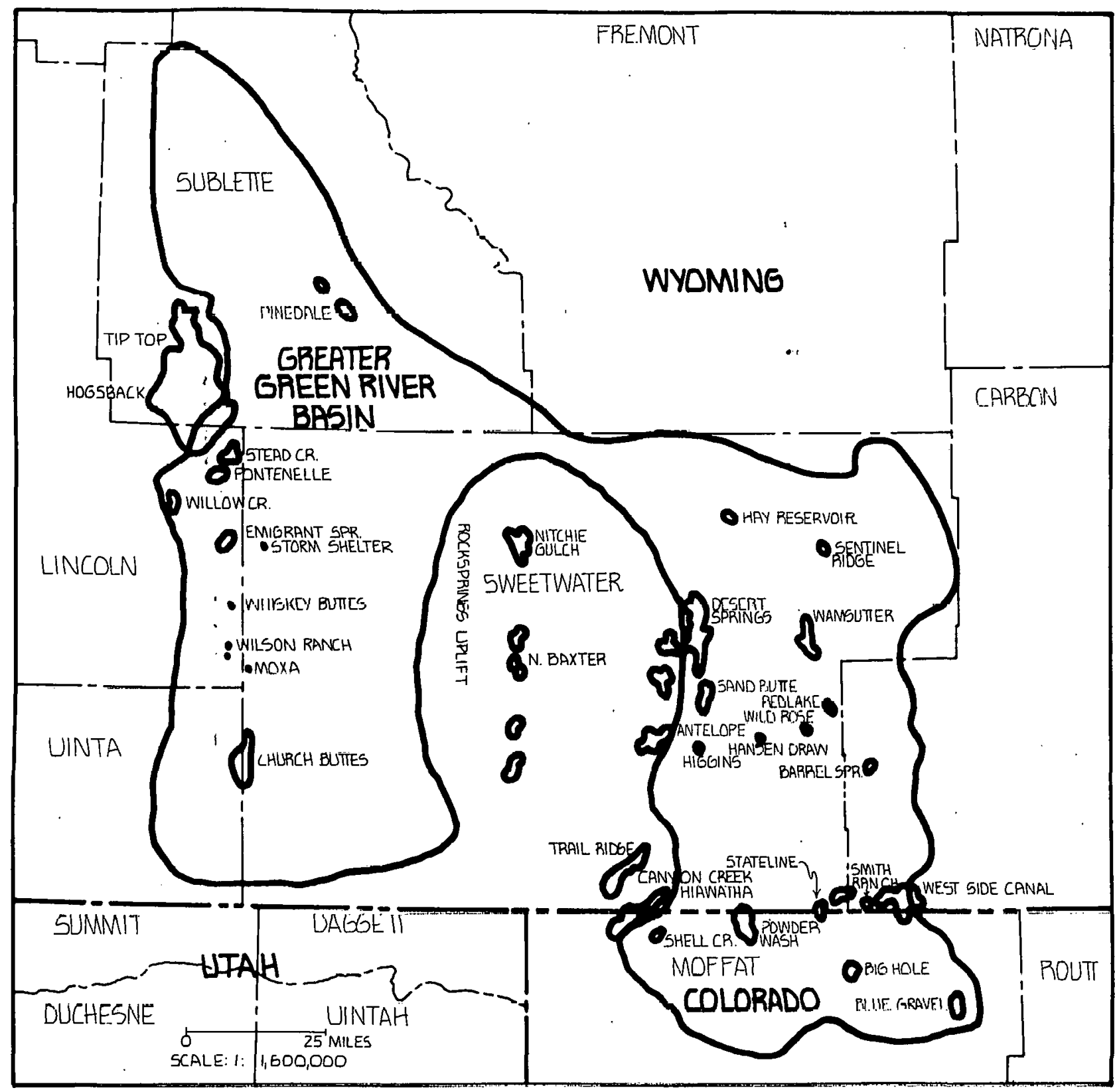

\section{FIGURE 3-1 MAP OF GREATER GREEN RIVER BASIN}


TABLE 3-1

\title{
INFORMATION ON CALLED OUT WELLS GREATER GREEN RIVER BASIN
}

\author{
1. Sun Oil \\ 1 Echo Springs - Federal \\ Sec 12-19N-93W \\ Carlan County, Wyoming \\ Echo Springs Field \\ Mesaverde Production $(9,303-9,330)$ ft gross \\ Wildcat outpost extension \\ Frac - 62,000 gal emul, 76,500-1bs of sd \\ IPF - 11,000 MCFD \\ 2. Davis Oil \\ \#1. Great Divide Unit \\ Sec 10-T23N-R96W \\ Sweetwater County, Wyoming \\ Lewis Production $(10,063-10,470) \mathrm{ft}$ \\ New Field Discovery \\ Frac - 250,000 lbs of sd, 143,700 gal. gel \\ IPF - 1,000 MCFD, 45 BCPD \\ 3. Davis Oil \\ Unit 8 \\ Sec $21-24 \mathrm{~N}-97 \mathrm{~W}$ \\ Sweetwater County, Wyoming \\ Hay Reservoir Field \\ Lewis Production $(10,038-10,086) \mathrm{ft}$ \\ Development Gas Well \\ Frac - 345,000 lbs of sd \\ IPF - 4,740 MCFD, 12 BCPD \\ 4. Mountain Fuel Supply \\ $F$ Wilson 25 \\ Sec 13-12N-100W \\ Moffat County, Colorado \\ Hiawatha Field \\ Ft. Union Production $(4,650-4,658) \mathrm{ft}$ \\ Development Gas Well \\ Frac - 99,620 1bs of sd \\ IPF - 1,187 MCFD
}


5. Mobil Oil

F 12-33G Unit TR5

Sec 33-T29N-RI130

Sublette County, Wyoming

Tip Top Field

Frontier Production $(6,810-7,599)$ ft gross

Development Gas Well

Frac - 410,000 lbs of sd

$1 / 8,000 \mathrm{gal}$. of emul

9,000 gal. of wtr

$1,000 \mathrm{gal}$. of acid

IPF - 4,011 MCFD

6. Pacific Transmission Supply

13-9 Federal

Sec 9-T25N-R.1.12W

Lincoln County, Wyoming

Fontenelle Fiald

Frontier test

perf $(8,400-8,428) \mathrm{ft}$

Frac - 1,000,000 lbs of sd

Testing

$510,000 \mathrm{gal}$. of wtr 


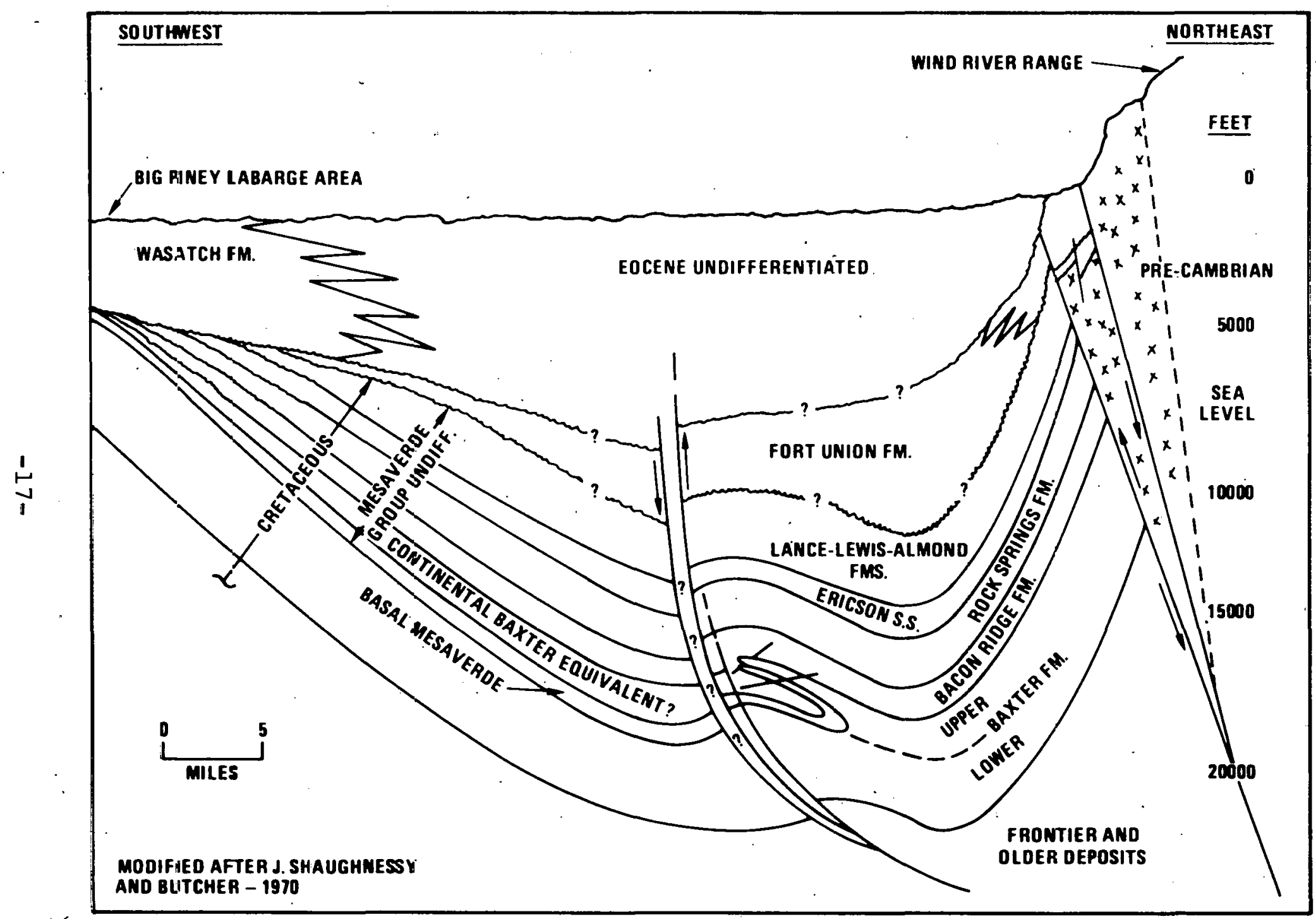

FIGURE 3-2 SCHEMATIC NORTHEAST-SOUTHWEST CROSS SECTION OF THE GREEN RIVER BASIN 


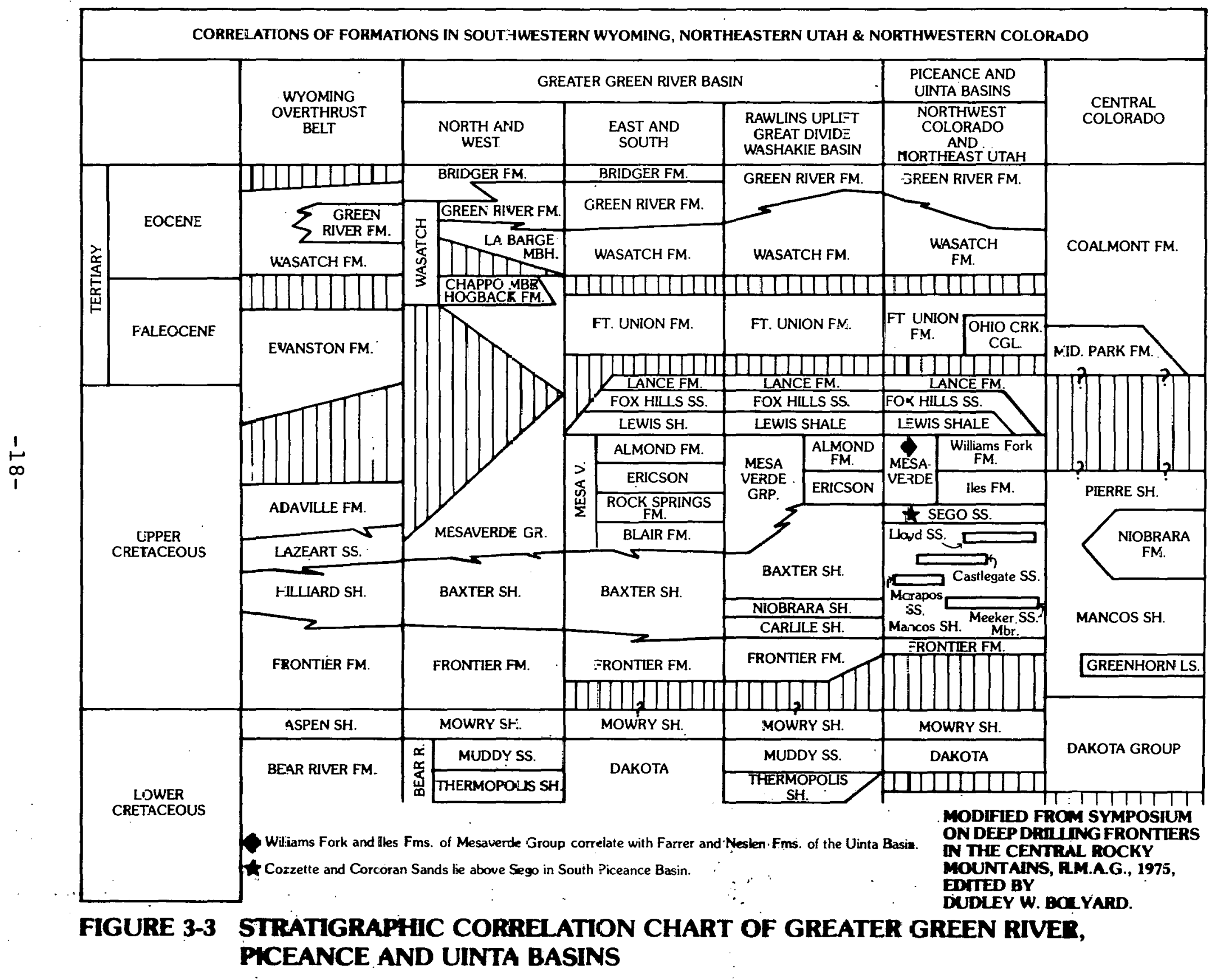


Suth of Wamsutter Field, in the Red Lakes and Wild Rose Field area, Amoco and Davis also have Mesaverde tests in operation with drilling depths varying from 10,000 to $11,000 \mathrm{ft}$. The 40 Amoco Production wells completed or tested in the wamsutter area have averaged 1 MMCFD on initial production. Further west, Amoco, Champlin and CIG Exploration are also drilling for Almond, Ericson, and Ft. Union production in the Hansen Draw Higgins Field area. Drilling depths to these objectives are 8,000 to $16,000 \mathrm{ft}$.

The Greater Green River Basin also occupies a part of Moffat County, Colorado, where Rainbow Resources, Mountain Fuel Supply and Champlin are active in exploring for Almond, Ericson, Lance and Ft. Union production. Depths vary from 4,000 to $10,000 \mathrm{ft}$ for these objectives. One Ft. Union pay zone in the Hiawatha Field yielded an initial production of 1,187 MCFD. The frac treatment was relatively small with 99,620 lbs of sand (callout 4).

Kenneth Luff, Davis Oil and Forest Oil are drilling for the Frontier and Dakota Sands on the Rock Springs Uplift of Wyoming's Sweetwater County but activity is limited to only a few wells. There is also some Morrison and Almond exploration by Kenneth Luff and Northwest Exploration to the north in the Nitchie Gulch area.

Further west in the Storm Shelter Field area, Davis Oil and $\mathrm{C} \& \mathrm{~K}$ Petroleum are drilling for the Frontier at depths between 10,000 and $11,000 \mathrm{ft}$. Frac treatments vary from 40,000 to over 400,000 lbs of sand. One $C \& K$ Petroleum well yielded an initial production flow of 1,000 MCFD from the Frontier. To the south of this activity, Amoco is exploring the Frontier at depths of over 12,000 ft and in Church Buttes Field, farther to the south, Mountain Fuel supply is testing the Frontier at $12,650 \mathrm{ft}$.

The northern extension of the Greater Green River Basin is in Sublette County. Here, Petro-Search, C.F. Braun and Chevron Exploration are actively drilling for the Frontier in the Birch Creek and Pinegrove Field areas at depths between 7,000 and $8,000 \mathrm{ft}$. Also in this arta, Mubil fraced the Frontier with 410,000 Ibs of sand and obtained an initial production of 4,01i MCFD (callout 5). Cabot Corporation and Belco Petroleum are drilling for the Mesaverde at about 2,500 ft in the North LaBarge area and Davis Oil is exploring the Frontier east of the Pinegrove Field area at depths of 15,000 to $16,000 \mathrm{ft}$. North of the Pinegrove Field area Pacific Transmission Supply is testing a Frontier wildcat, while still farther to the north, Rainbow Resources has a 16,800 ft Frontier test planned. In Lincoln County, Marathon, Amoco and Pacific Transmission are active in the Wilson Ranch, Whiskey Buttes and Fontenelle Field areas. Again, the primary objective is the Frontier at depths of 8,000 to $11,000 \mathrm{ft}$. A Fontenelle well was fraced with $1,000,000$ lbs of sand and it is presently on test. while a Marathon well, 30 miles to the south, with an unknown size frac job, yielded an initial production of 3,076 MCFD 
(callout 6). Amoco has nine Frontier tests working in the Whiskey Buttes area and Pacific Transmission has five in the Fontenelle area.

In Uinta County, Mountain Fuel recently completed a Frontier test at $11,700 \mathrm{ft}$ with an initial flow of 1,870 MCFD. Phillips Petroleum and Amoco are also active in this area. 


\section{UINTA BASIN}

\subsection{General Geologic Description}

The Uinta Basin in northeast Utah shown by Figure 4-1, is a major sedimentary basin bounded on the north by the Uinta Mountain Uplift and on the west by the Wasatch Mountain Uplift. The basin is bounded on the southwest and southeast by the San Rafael Swell and uncompahgre Uplift. The southern basin edge is usually considered to be the Book Cliffs. On the east, the Uinta Basin is separated from the Piceance Basin by the Douglas Creek Arch. The basin is asymmetric with the structural axis close to the Uinta Mountains on the north. The basin contains over $30,000 \mathrm{ft}$ of sedimentary rock in the northern part. The Upper Cretaceous, Paleocene and Eocene intervals account for 80 percent of the total amount.

The oldest producing formation in the basin is the Permo-Pennsylvanian Weber Sandstone. Oil and gas are also produced commercially from the Mesaverde Group as well as from Lower Cretaceous and Jurassic rocks. Large quantities of gas and oil are produced from Tertiary Wasatch and Wasatch equivalents, Green River and Uinta Formations. Gas accumulations in the Uinta Basin are essentially all stratigraphic with productivity restricted due to low porosity and permeability.

As in the Piceance Basin, these beds represent a wide variety of nonmarine depositional environments with some marine beds (Lower Mesaverde). The Mesaverde is exposed along the margin of the basin but will require drilling depths of about 18,500 ft in the deeper parts for total penetration to the Mancos Shale. It can be in excess of 5,000 ft thick. Figure 4-2 shows the east-west diagramatic cross section of the Uinta Basin.

\subsection{Basin Activity}

Most activity in the Uinta Basin has been in the Natural Buttes and Chapita Wells units of Uintah County, Utah. At present, there are about 40 wells proposed, recently drilled, or completed in this area. The primary objectives are the tight Tertiary Wasatch and Upper Cretaceous Mesaverde. Initial production (IP) varies from less than 700 to over 2,000 MCFD. The Wasatch, having less resource potential than the Mesaverde, is presently the most productive zone. One Belco Petroleum well produced an IP of 3,560 MCFD from the Wasatch while still another produced an IP of 5,684 MCFD from the same formation. The well locations are shown on Figure 4-1 with specific information listed in Table 4-1. 


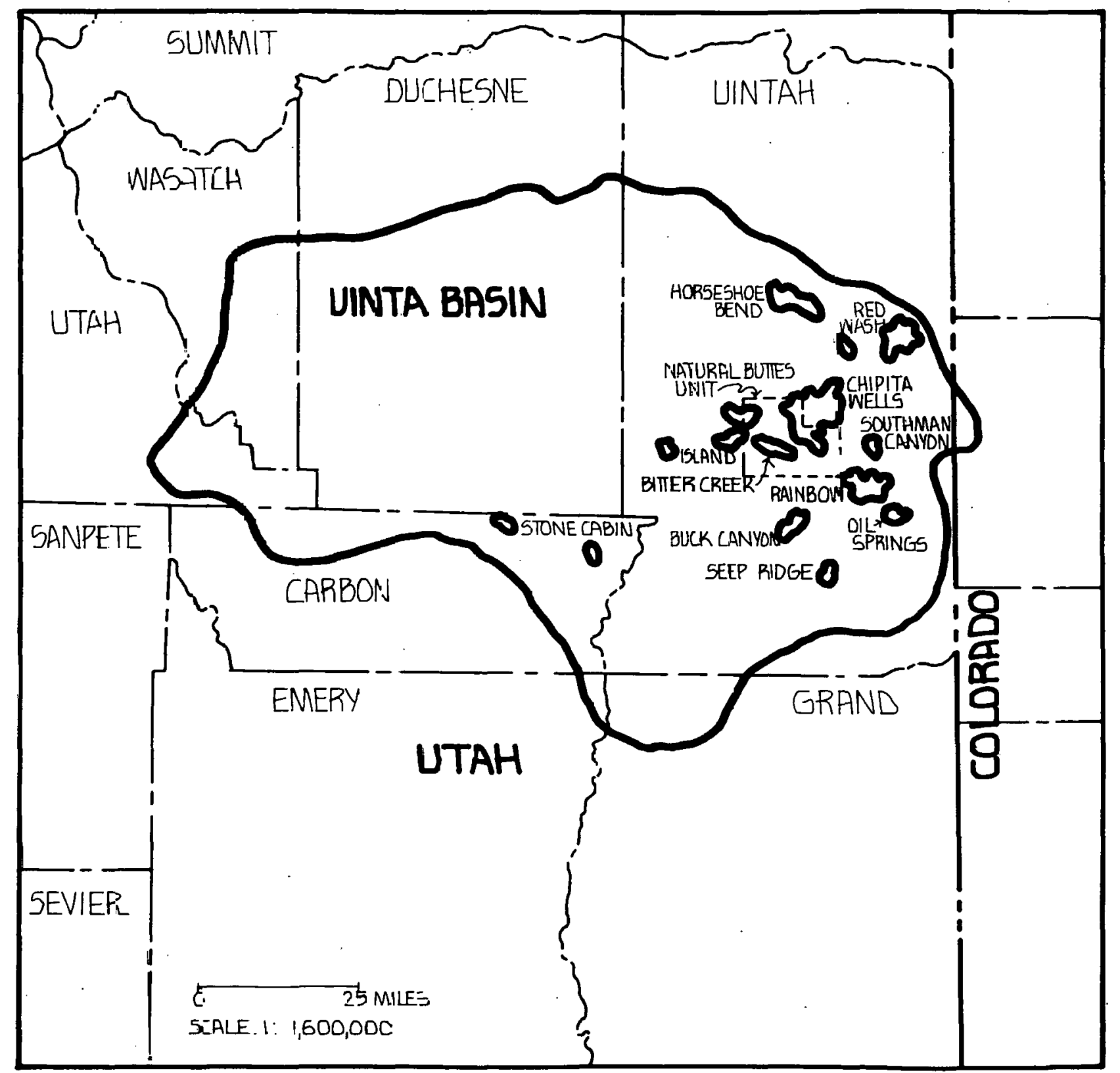

FIGURE 4-1 MAP OF UINTA BASIN 


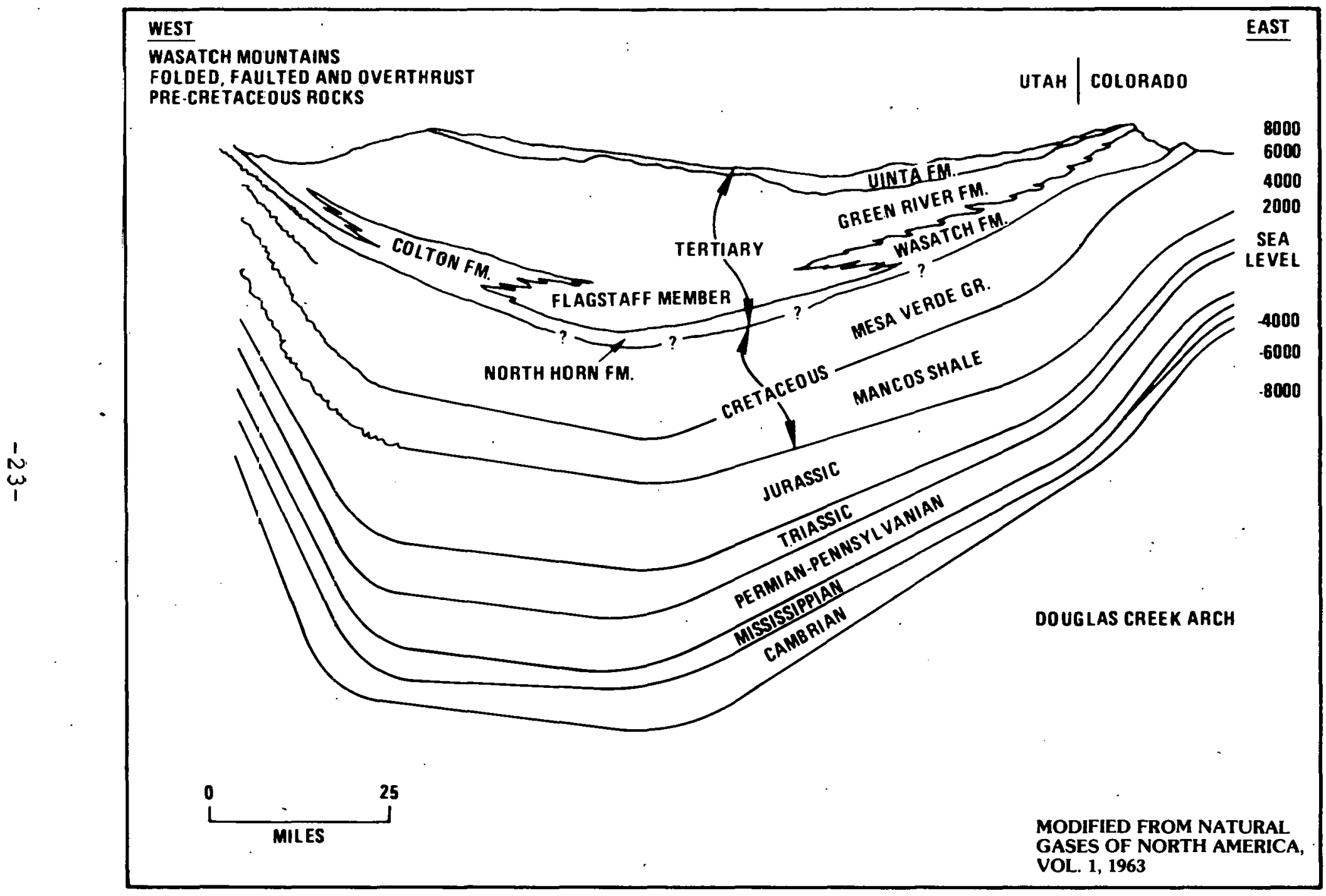

FIGURE 4-2 EAST-WEST DIAGRAMMATIC CROSS SECTION OF THE UINTA BASIN 


\section{TABLE 4-1 \\ INFORMATION ON CALLED OUT WELLS \\ OF THE UINTA BASIN}

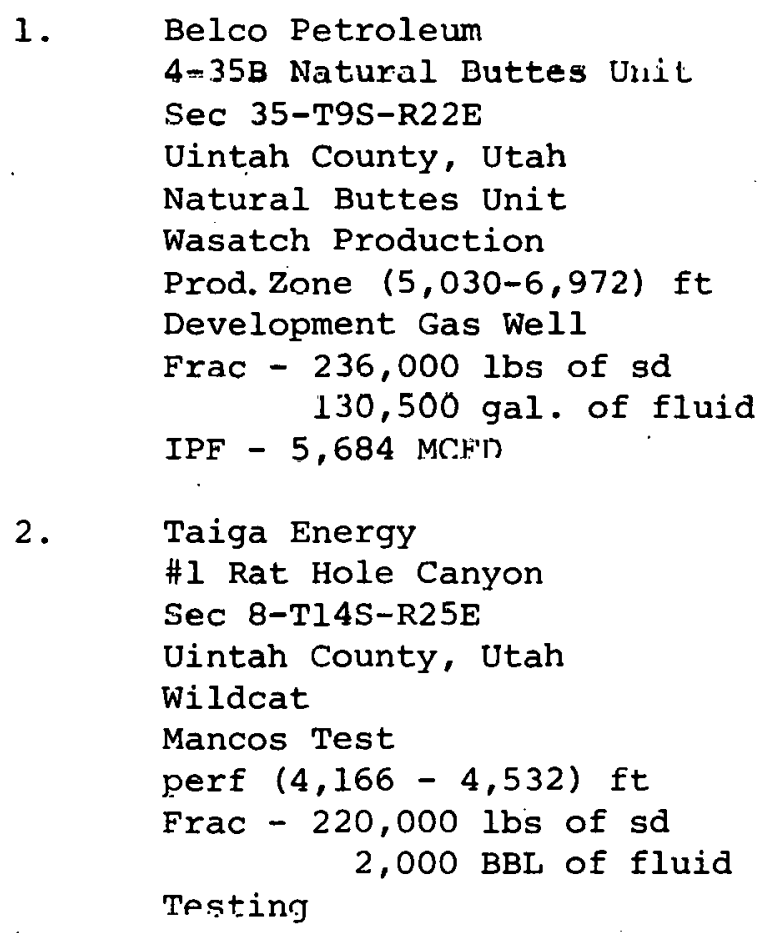


Taiga Energy is drilling for the Mancos in the southern part of Uintah County. Frac sizes are about 200,000 Ibs of sand. No production data is available at this time.

In the Natural Buttes area, GPE and CIG are also drilling for the Mancos. On November 21, 1977, a MHF experiment was conducted on GPE's Natural Buttes No. 22 well. Post frac cleanup is proceeding. 


\section{PICEANCE BASIN}

\subsection{General Geologic Description}

The Piceance Basin of northwest Colorado is bounded by the Uinta Mountains and Axial Basin Uplift on the north, the Douglas Creek Arch on the west, the Uncompahgie Upllft on the south, and the Grand Hogback (White River Uplift) and Elk Mountain on the east, (Figure 5-1). Total area of the basin is 3,900 square miles encompassed by an almost continuous outcrop of the Tertiary-Cretaceous contact. This strongly asymmetric basin contains a maximum thickness of about 27,000 feet of sedimentary rocks. This figure represents the maximum structural relief of Pre-Cambrian surface betwcen the luwest point. in the basin and the lipylest point on the white River and Uncompahgre Dpliftc. The rovks ldnye in àge from Cambrian to Eocene, (Figure 5-2).

The Paleozoic and Lower Mesozoic rocks represent a variety of marine and non-marine environments with oil and gas production from various formations. During Upper Cretaceous time, northwestern Colorado was the site of marine transgressions from the north and east with subsequent regressions. These resulted in a thick wedge of dominantly marine prodeltaic mudstones (Mancos Formation) in the lower half of the interval and an upper half of dominantiy non-marine rocks (Mesaverde Group). Mesaverde sandstones, shales, and coals record the easterly retreat of the seas and the advance of a large littoral marine and coastal-plain complex. Lower Tertiary rocks in the basin (also nonmarine) consist of thick wedges of siliciclastics which thin westerly and interfinger in part with lacustrine carbonate and siliciclastics toward the basin center.

The Western Gas Sands Project is primarily concerned with the Mesaverde Group, North Horn, Fort Union, Colton, Wasatch, and Green River Formations or their equivalents. Natural gas is contained in stratigraphic traps, some enhanced by structure, in low-permeability sands and silts. The depositional environments probably represent a wide variety of non-marine conditions with a few intercalated marine beds in the lower part of the Mesaverde.

The Mesaverde Group is characterized in part by fluctuating shoreline sedimentary environments, which contain abundant stratigraphic traps which are transitional with adjacent non-marine bede. A limited volumc of gas is produced commercially from the Mesaverde in the southern part of the basin. General sandstone characteristics of the Upper Mesaverde include lenticular sand bodies with a wide range of thicknesses, but of limited lateral extent, (Figure 5-3). The sandstone has abundant clay and silt with widespread low permeability fractures. Some of these sand lenses may also contain small impermeable shale barriers which inhibit gas flow. 
The Mesaverde is sometimes in excess of 5,000 feet thick; drilling depths for total penetration range from zero at the outcrop to 12,000 feet in the deeper parts of the basin.

Gas is also produced from Fort Union (Paleocene) and Wasatch (Eocene) sandstones in the basin. The top of the Fort Union is about 1,000 feet above the top of the Mesaverde, while the top of the Wasatch Formation occurs about 2,500 feet higher in the section. Potentially favorable zones are expected in these sediments over various parts of the basin.

\subsection{Basin Activity}

There are two areas of concentrated activity in this Basin. In the western part of the Rio Blanco County, Tipperary Oil and American Resources Management are active in the Trail Canyon Field, while Lawrence Barker, Jr. and Taiga Energy are active in the South-Douglas Creek and Thunder Fields, (Figure 5-1). The wells called out in the text are shown in Figure 5-1, along with significant gas fields. Table 5-1 then gives specific information on each well called out. To the north in Cathedral, Dragon Trail, and Lower Horse Draw there is activity by Fuel Resources, Twin Arrow, Chancellor and Ridgeway, Chandler and Associates, and John Brunel. Their main objectives are the Mancos "B" or Emery zones. Currently, there are over 60 Mancos tests being actively drilled, or in the planning stages in Rio Blanco County alone. L. Barker fraced the Mancos "B" zone in one South Douglas Creek Field with almost 200,000 lbs of sand receiving an initial flow of 157 MCFD (callout 1). Taiga Energy has eight Mancos tests in progress in Thunder Field. The Cathedral Field had two Mancos tests with an initial production of 280 and $990 \mathrm{MCFD}$ (callout 2). The frac treatments ranged from 160,000 to $180,000 \mathrm{lbs}$ of sand. Northwest Exploration has plans for a ten-well program in this field and has recently begun drilling. Mobil Oil is active in the Piceance Creek Field with Wasatch and Mesaverde exploration. One wasatch test initially produced 2,480 MCFD on a 140,000 Ib frac at 3,000 feet. Several other more recent wasatch tests have also been successful.

The other major activity includes and surrounds the Plateau Field of eastern Mesa County. Major operators include Flying Diamond Oil, Apache Corporation and Adolph Coors. There are about ten tests for the Upper Cretaceous Cozzette and Corcoran Sands at depths from 3,000 to 9,000 ft. Norris Oil recently completed two wells with Rollins, Cozzette and Corcoran production. Fracs were over 250,000 1 bs of sand with an initial production of 1,300 to 1,600 MCFD (callout 3). Exxon successfully fraced the cozzette outside the field with 105,000 lbs of sand receiving an initial production of 840 MCFD. 


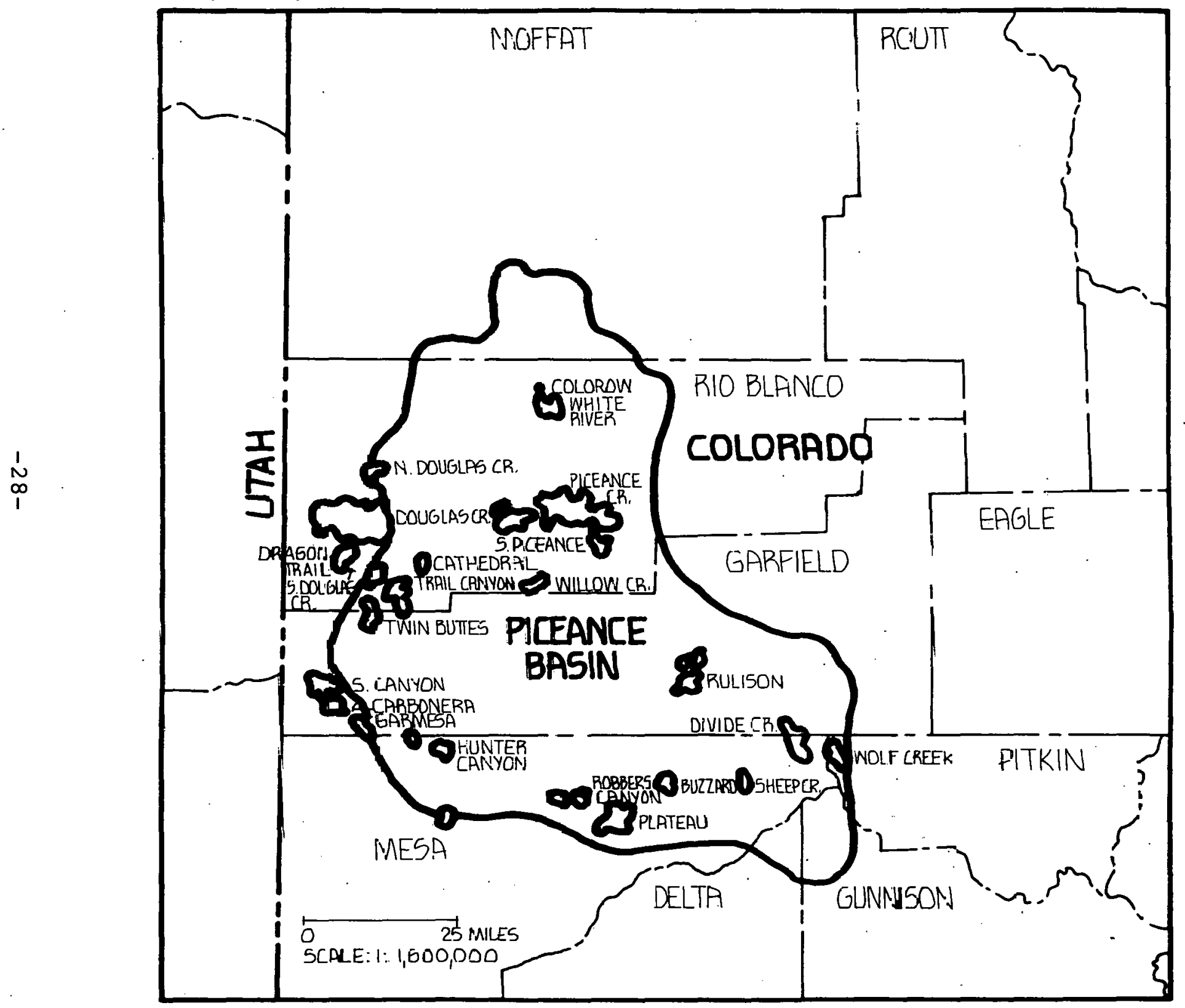

FIGURE 5-1 MAP OF PICEANCE BASIN 


\section{TABLE 5-1 \\ INFORMATION ON CALLED OUT WELLS OF THE PICEANCE BASIN}

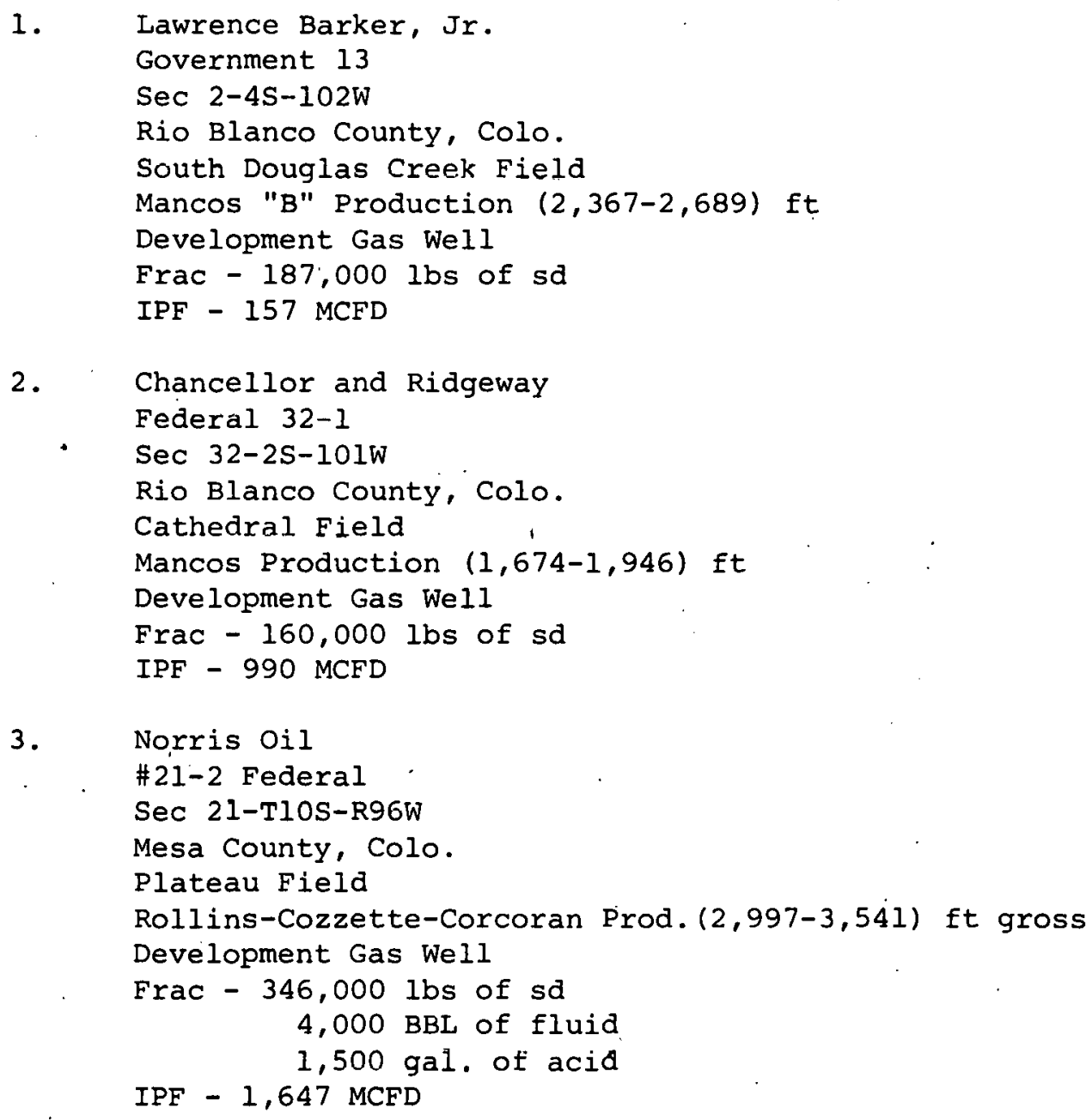

2. Chancellor and Ridgeway

Federal 32-1

Sec 32-2S-101W

Rio Blanco County, Colo.

Cathedral Field

Mancos Production $(1,674-1,946) \mathrm{ft}$

Development Gas Well

Frac - 160,000 lbs of sd

IPF - 990 MCFD

3. Norris Oil

\#21-2 Federal

Sec 21-T1OS-R96W

Mesa County, Colo.

Plateau Field

Rollins-Cozzette-Corcoran Prod. $(2,997-3,541)$ ft gross

Development Gas Well

Frac - 346,000 lbs of sd 4,000 BBL of fluid

1,500 gal. of acid

IPF - 1,647 MCFD 


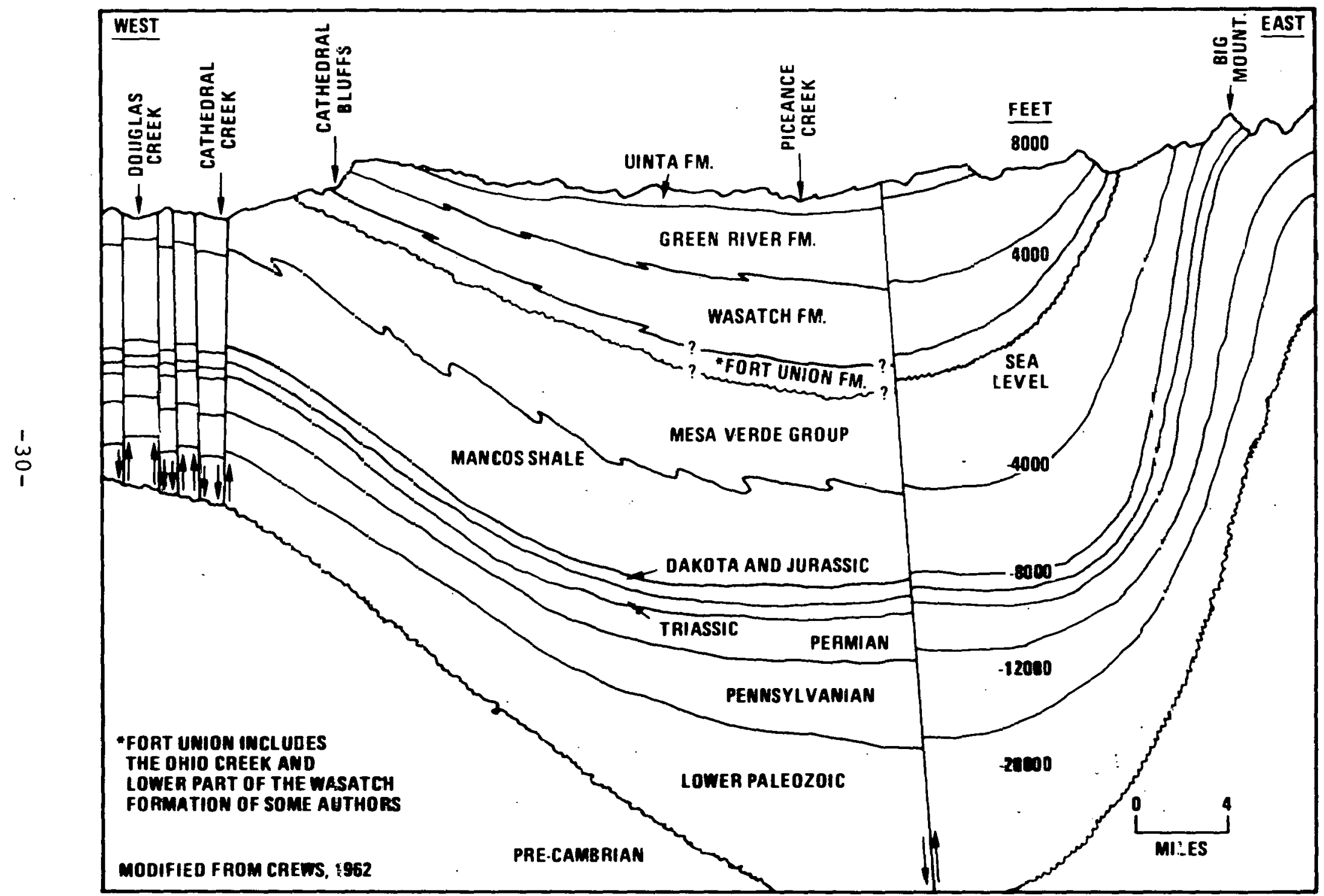

FIGURE 5-2 SCHEMATIC EAST-WEST CROSS SECTION OF THE PICEANCE BASIN 


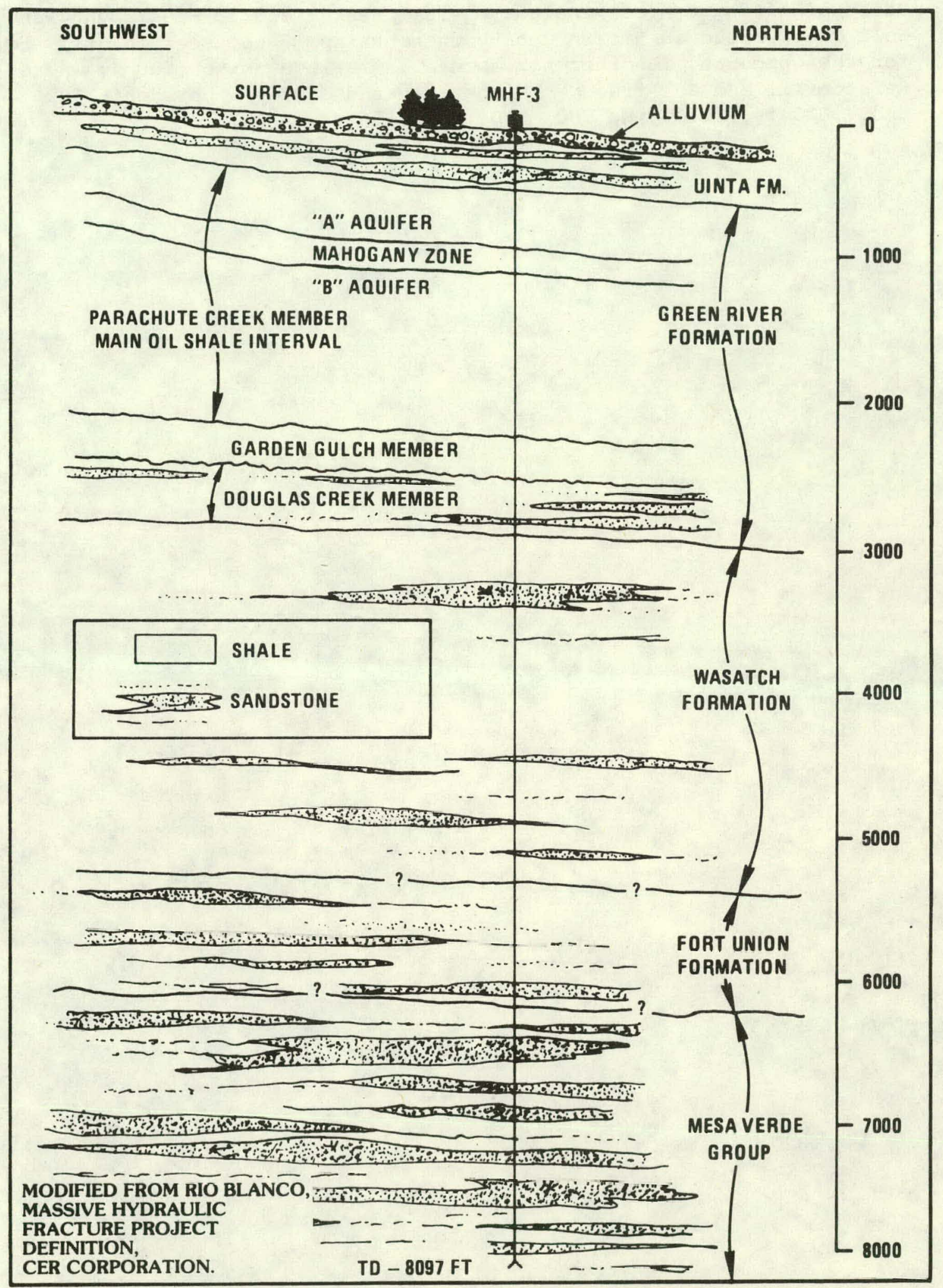

FIGURE 5-3 TYPICAL STRATIGRAPHIC RELATIONSHIPS OF LENTICULAR SANDS IN THE UPPER CRETACEOUS AND LOWER TERTIARY OF THE PICEANCE BASIN. 
Other significant areas include Divide Creek Field in Mesa County and Wolf Creek Field in Pitkin County where Rainbow Resources is drilling for the Corcoran. Another noteable area is in Gunnison County where Ralston Oil and Gas fraced the Cozzette and Corcoran between 6,500 and 7,000 ft, receiving 880 MCFD. 